\author{
Sarah Fassio \\ (1) https://orcid.org/0000-0003-3893-9817 \\ European University Viadrina Frankfurt (Oder) \\ Fassio@europa-uni.de
}

Jessica Hodgkiss

๑ https://orcid.org/0000-0002-1189-3612

European University Viadrina Frankfurt (Oder)

Hodgkiss@europa-uni.de

\author{
Adrianna Rosa \\ @ https://orcid.org/0000-0003-4180-9343 \\ European University Viadrina Frankfurt (Oder) \\ kuma-hiwi@europa-uni.de
}

\title{
ON THE INCOMPATIBILITY OF SCIENCE AND ART - A QUANTITATIVE SURVEY TO DETERMINE THE RELEVANCE OF AN ACADEMIC DEFINITION OF ART FOR ARTISTS
}

\footnotetext{
Abstract: Since Greek Antiquity, art historians, philosophers and sociologists alike have been engaged in an academic discourse to find a definition for art. It seems, however, to lie in the very nature of art to continuously redefine itself. The endeavor of developing a theoretical construct for the visual arts appears therefor to succeed only in part; art seems always a step ahead of science. A scientific perspective on the concept of art still dominates literature today. This article highlights the artist's perspective and shows what role a scientific approach to the concept of art plays in artistic practice while also identifying alternative possibilities to define art. A quantitative survey among 80 visual artists revealed that they consider a scientific definition of art as rather irrelevant, a majority even deeming it unnecessary. Instead, they see artists as key figures on the art market, positioning themselves before art historians or curators when it comes to determining what art is. When it comes to the question of who ultimately defines the concept of art, it becomes clear that a certain incompatibility between art theorists and visual artists exists. Based on the insights gained, this study concludes with implications for further developing
} 
theories on the concept of art, proposing to better integrate artists in their roles as researchers in order to achieve more dynamic and adaptable approaches.

Keywords: Art and Science, Definition of Art, Concept of Art, Art Theory, Artist as Researcher, Visual Artist, Quantitative Research, Artist Survey

\section{Introduction}

Philosophers have pondered the concept of art and its role in society since Greek antiquity. ${ }^{1}$ The emergence of art history as an academic discipline, and of art criticism and finally, of sociology of art, has led academics to examine art from different perspectives. Sharing a common endeavor, namely to find a universal definition of art, they aimed to elevate art into a societal context. However, the attempt to put forward a general definition of art holds a contradiction in itself; art must be created for its own sake, free from any constraints or purposes. History shows how artists have repeatedly questioned or even overhauled the then-prevailing concepts of art with Expressionism serving as perhaps the best example to date. ${ }^{2}$ Despite this fact, art theorists' views on the concept of art largely dominate literature and are marked by a rational and generalizing approach. Since the late 20th century, however, there has been an increasing demand to strengthen artists in their role as researchers and to better involve them in the process of forming new theories. ${ }^{3}$ "Artists who engage in research, investigate and experiment in a way that develops and widens the ability to perceive each other and the world around us" ${ }^{4}$ may provide science with new approaches and concepts thus contributing significantly to ongoing research on art.

But what is the relationship between art theory and artistic practice, between theorists and artists today? This article explores to what extent theories on the concept of art influence artists in their production and which factors they themselves consider crucial in defining art. In order to determine European artists' views on art theory, the authors conducted a qualitative study that would offer significant insights. Hoping to make a contribution to bridging the research gap in this field, the authors considered existing ideas for artistic research on the concept of art.

\footnotetext{
1 A. Dresdner, Die Entstehung der Kunstkritik im Zusammenhang der Geschichte des europäischen Kunstlebens. Verlag der Kunst Dresden, Dresden 1968, p. 41.

2 G. Dickie, Introduction to Aesthetics: An Analytic Approach, Oxford University Press, Oxford \& New York 1997, pp. 45ff.

3 E. Lilja, ART, RESEARCH, EMPOWERMENT: On the Artist as Researcher, Elanders Sweden AB, Stockholm 2015, p. 106.

4 Ibid., p. 10
} 
This article will first provide some basic definitions of key terms concerning art, artists, and art theory. A presentation of the empirical investigation and its findings will follow. After a closing discussion of the obtained results, the authors will present implications for future research on the concept of art that will see the artist as an active participant in theory formation.

\section{Theoretical Framework}

\subsection{Definitions: Art, Artist, Concept of Art}

In the 18th century a set of five arts established itself - painting, sculpture, architecture, poetry and music - known henceforth as the 'fine arts.' The term 'fine' refers to an art without purpose, characterized by beauty, skill, grandeur, elegance or perfection. ${ }^{5}$ The visual arts include painting, sculpture, graphic media and, to a certain extent, architecture. ${ }^{6}$ The visual artist is the creator of such artworks and therefore assumes a central role in the art world. The Künstlersozialkasse - the largest social insurance provider for visual artists living in Germany - defines the artist as someone who produces, performs or teaches music, performance or visual arts. ${ }^{7}$ No acquired qualifications are necessary to call oneself an artist. ${ }^{8}$ Indeed a definition of 'artist' is impossible, as any definition would impose constraints. For this reason, no definition exists, which in turn results in tensions between artistic practice and art theory.

A theory of art can be anything from a "complex philosophical treatise to a few basic observations jotted down by an artist that illuminate the direction of his work."9 A more stringent definition of art theory is its description as "a conceptual framework, series of principles, or set of substantive theses that explain the appearance, structure, function, or significance of works of art." 10 A concept of art is subject to a specification of "necessary and sufficient conditions needed for something to be a work of art," 11 as determined by a philoso-

5 J. A. Walker, Art in the Age of Mass Media, Pluto Press, London 2011, pp. 6 .

6 U. Weisstein, Literatur und bildende Kunst. Andy Warhol und der Umbau des Kunstbetriebs im 20. Jahrhundert, Campus Verlag GmbH, Frankfurt/Main 1992, p. 9.

7 Künstlersozialkasse Deutschland, Voraussetzungen für eine Versicherung bei der KSK: https:// www.kuenstlersozialkasse.de/kuenstler-und-publizisten/voraussetzungen.html (access: 12 July 2019).

8 H. Abbing, Why Are Artists Poor? The Exceptional Economy of the Arts, University Press, Amsterdam 2002, p. 278.

9 J. C. Taylor, Nineteenth Century Theories of Art, University of California Press, Berkeley/ Los Angeles/ London 1987, p. I.

10 D. Costello, J. Vickery, Art: key contemporary thinkers, Berg Publishers, Oxford \& New York 2007, p. 3.

11 G. Dickie, Introduction to Aesthetics: An Analytic Approach, Oxford University Press, Oxford $\&$ New York 1997, p. 50. 
pher. "Any theory of art (...) attempts to specify defining characteristics, which are going to be rather narrowly restricted and simply will not reflect the broad scope of things that works of art do." 12

A brief historical outline shows that the theoretical principle of artistic creation in ancient Greek times was imitating reality. Plato criticized representational art, seeing in it a source of illusion that was able to evoke feelings and corrupt the beholder. ${ }^{13}$ Aristoteles, while concerning himself foremost with poetry, regarded art as cathartic. ${ }^{14}$ The imitation theory prevailed up until the 19 th century when it was challenged by Expressionism. While hitherto the object properties of artworks were regarded as essential, the expressionist theory centered on the artist's role, taking into consideration the artist's emotional state for which the artwork served merely as a means for expression..$^{15}$ As is evident from the example of Expressionism, art has repeatedly challenged art theory in the past. A precise definition of art is difficult - especially considering the fact that from the late 20th century onwards more and more styles emerge that no longer fit into classical genres.

\subsection{Current State of Research on the Concept of Art}

\subsubsection{Current State of Research: Concept of Art as Defined by Academics}

The concept of art has been examined from different perspectives, including philosophical-aesthetic (Weitz 1956), historical (Levinson 2002) and sociological (Eaton 1983), leading to numerous debates among scholars. While some argue that a definition of art is impossible (Beardsley 1958, Weitz 1956), others name conditions under which defining art is plausible, stating art history (Danto 1964), the art circle (Dickie 1984), as well as other properties.

Arguments have ensued as to whether beauty lies at the core of the concept of art. Monroe Beardsley declares that aesthetic experience is a factor that makes something a work of art ${ }^{16}$ According to George Dickie, such a definition would however, exclude artworks such as ready-mades, leading Beardsley to reclassify such pieces as 'comments' on art. ${ }^{17}$ That art goes beyond evoking aesthetic pleasure and serves as a source for meaning has equally been widely discussed among theoreticians. In her collection of writings, Against Interpre-

12 Ibid., p. 102.

13 R. Stecker, Plato, in: Aesthetics: The Key Thinkers, A. Giovannelli ed., Continuum, London, New York 2012, p. 13.

14 G. Dickie, Introduction to Aesthetics: An Analytic Approach, Oxford University Press, Oxford \& New York 1997, p. 47.

15 G. Dickie, Introduction to Aesthetics: An Analytic Approach, Oxford University Press, Oxford \& New York 1997, pp. 45ff.

16 Ibid., p. 29.

17 N. Carroll, Monroe Beardsley, in: Aesthetics: The Key Thinkers, A. Giovannelli ed., Continuum, London, New York 2012, p. 160. 
tation and Other Essays (1961), Susan Sontag highlights art's spiritual importance. Her seminal work Aesthetics of Silence (1967) regards art as a substitute for religion, posing a problem, however, as the artist's tools themselves are of a material nature. Sontag concludes that art can't provide the artist with a desired realization or transcendence. ${ }^{18}$

The broad scope of scientific research on the subject makes a selection of sources almost impossible. Among endless attempts to define art a vast number of treatises on art itself exist. In the following, the authors will make their best attempt at presenting essential literature that comprises concepts of art as well as citing a small number of leading theoreticians.

In Definitions of Art (1991), Stephen Davies describes and comments on the topic of defining art while offering a thorough collection of proposed definitions as discussed in Anglo-American philosophy from the 1950's onwards. In an attempt to outline definitions of art, Noël Carroll features a number of major players in his volume Theories of Art Today (2000). Joshua C. Taylor compiles late 18th and 19th century writings on the subject in his publication Nineteenth Century Theories of Art (1987) and contributes to Herschel B. Chipp's volume Theories of Modern Art (1968). Scientific papers include Morris Weitz' seminal work The Role of Theory in Aesthetics (1956), while more recent scholarly articles on the subject include pieces such as The Irreducible Historicality of the Concept of Art (2002) by Jerrold Levinson and Gregory Currie's take on Levinson's definition in his contribution Actual Art, Possible Art, and Art's Definition (2010).

A leading voice among theorists, Morris Weitz - though negating a definition of art - paved the way for a "consideration of complex, nonexhibited relational features of art" 19 as opposed to a hitherto exploration of "intrinsic, exhibited, defining characteristics." ${ }^{20}$ Due to logical fallacies however, his theory has since come under scrutiny. ${ }^{21}$ Weitz describes on one hand the need for an open concept under which art is receptive to change, and on the other a search for similarities in established artworks in order to identify new works of art, a concept he terms 'family resemblances.'22

An example of a historical approach in defining art is Jerrold Levinson's theory, which he provides in The Irreducible Historicality of the Concept of Art (2002).

18 S. Sontag, Aesthetics of Silence in: Aspen no. 5 + 6, item 3, 1967, p. 2: http://www.kim-cohen. com/Assets/CourseAssets/Texts/Sontag_The\%20Aesthetics\%20of\%20Silence.pdf (access: 12 July 2019).

19 S. Davies, Definitions of Art, Cornell University Press, Ithaca, London 1991, p. 2.

20 Ibid., p. 2.

21 N. Carroll, Theories of Art Today, The University of Wisconsin Press, Madison \& Wisconsin 2000 , pp. 5 f.

22 Ibid., pp. $5 f$. 
In his contribution to Carroll's volume, titled The Institutional Theory of Art, Dickie cites five elements that enable a definition of art. These include the artist as "a person who participates with understanding in the making of a work of art" 23 - an artwork being an artifact presented to a versed public. Thus, Dickie embeds the artist within a social context, namely the art circle. According to Luhmann's systems theory, art and science are two individual function systems within society. While science is solution-oriented and reduces possible answers to a minimum, art offers the maximum of potential response. ${ }^{24}$ Science and art operate in two different directions: once containing and once expanding social issues. Could this fact serve as an indication as to why it is so difficult to determine a theory for the concept of art? If indeed two distinct spheres pursuing different objectives exist, this might very well be the reason for their incompatibility.

\subsubsection{Current State of Research: Concept of Art as Defined by Artists}

In Theories of Modern Art (1968), Herschel B. Chipp offers a compilation of original artists' statements in form of letters, articles and speeches, featuring numerous artists' theories based on their own work as well as artist-formulated manifestos. Artists can be considered legitimate commentators on their own art, with ideas and theories that influence them stemming largely from science, history, literature, political or social theory, or art periods. Studying theoretical documents requires caution and must take into consideration factors such as cultural context of the times, ideological milieu, the medium as well as the writer's personal qualifications as a theoretician. ${ }^{25}$ Chipp goes on to propose that "academic training may provide either a viable for individual development (...) or it may impose rigid shackles that can be broken only by an act of force. Written and spoken ideas may be a fertile source of plastic images (...) or they may seem to the artist to pose the threat of <<literary ideas $>>$ that should be resisted at all costs." 26

Using the example of Symbolism, Chipp outlines how art theories offer an ideological background for artists of a certain movement. Concerning artistic problems, the Symbolist artists were widely influenced by theories of poets whom they were often personally acquainted with. One of the founders of Art

23 G. Dickie, The Institutional Theory of Art, in: N. Carroll ed., Theories of Art Today, The University of Wisconsin Press, Madison \& Wisconsin 2000, pp. $96 f$.

24 J. Hörisch, Der Wert der Kunst. Oder: Was leistet Kunst, wer kann und soll sich bildende Kunst leisten? [Lecture Paper]. Berlin, Akademie der Künste, BBK-Symposium „Kunst Wert“, 27.10.2017, p. 3.

25 H. B. Chipp, Theories of modern art: A source book by artists and critics, University of California Press, Berkeley 1968, pp. 1f.

26 Ibid., pp. 3f. 
Nouveau, artist Henri van de Velde was for instance, strongly influenced by William Morris' early social theories. ${ }^{27}$

Other compilations of artist's statements exist that offer first-hand information on artist's views. In his volume The Aesthetic Theories of French Artists (1950), Charles E. Gauss offers insights into the writings of artists on their own artworks. Similarly, Alfred Werner contributes to the subject on 'artists who write' in his eponymous publication from $1965 . .^{28}$

Today, art has become a field of research in itself. In Art, Research, Empowerment - The artist as researcher (2015), Efwa Lilja explores the artist's role in developing theories on equal footing with other fields of knowledge, thus contributing to the advancement of theories within the arts. Lilja states her concern on the current state of art education as having a tendency to cite theories from philosophy and humanities rather than artistic theories. Indeed, referencing concepts on art by theorists is far more common than proposals put forward by artists. Clearly, artists' practical research is still in its infancy. This article aims to address precisely this issue and to determine to what extent art theories play a role in artists' everyday practice, and if indeed they don't, what does?

\section{Methodology}

In order to obtain substantial results regarding the research question, the authors opted for a qualitative research design. Published annually and offering key figures on the global art market, the Art Market Report from 2019 served as a basis for sample formation. The report lists countries that account for the largest market shares in the EU market. For 2018, these included the United Kingdom (66\%), France (19\%), Germany (4\%), Spain (2\%), Italy (2\%), Austria (2\%) and Sweden (1\%). ${ }^{29}$ Grouped together as "Rest of EU", remaining countries made up four percent of the European art market. As not further specified in the report, they weren't included in this investigation.

In a next step, the authors contacted the largest art and artist associations in the seven selected countries, requesting them to forward the survey to their artist networks. The approach was intended to ensure that only professional visual artists took part, which in turn would produce undistorted results. In addition to recording demographic facts as well as the extent and focus of artistic activity, the survey examined to what extent the participants concern themselves with theories on the concept of art and what role these theories play 
in their daily work. Participants were able to skip individual questions. Some questions offered participants the possibility to comment in writing. For the purpose of painting a more accurate and vivid picture, the authors will present some of the artists' remarks in the course of this investigation. Created on 12 June 2019, the survey noted its first participant on 18 June and closed on 7 July 2019.

\section{Findings}

A total of 80 visual artists from over 11 different countries took part in the survey (see fig. 1). 86 percent of the participants had studied, 14 percent were self-taught. No participants under the age of 20 took part. The majority of the participating visual artists ranged between 20-30 (18\%), 30-40 (38\%), 40-50 (32\%) and 50-60 years of age (9\%). Three percent of the participants were over 60 . There were more male than female participants (60\% to $39 \%)$. The remaining one percent didn't specify their gender.

Q: Where do you currently spend most of your time working?

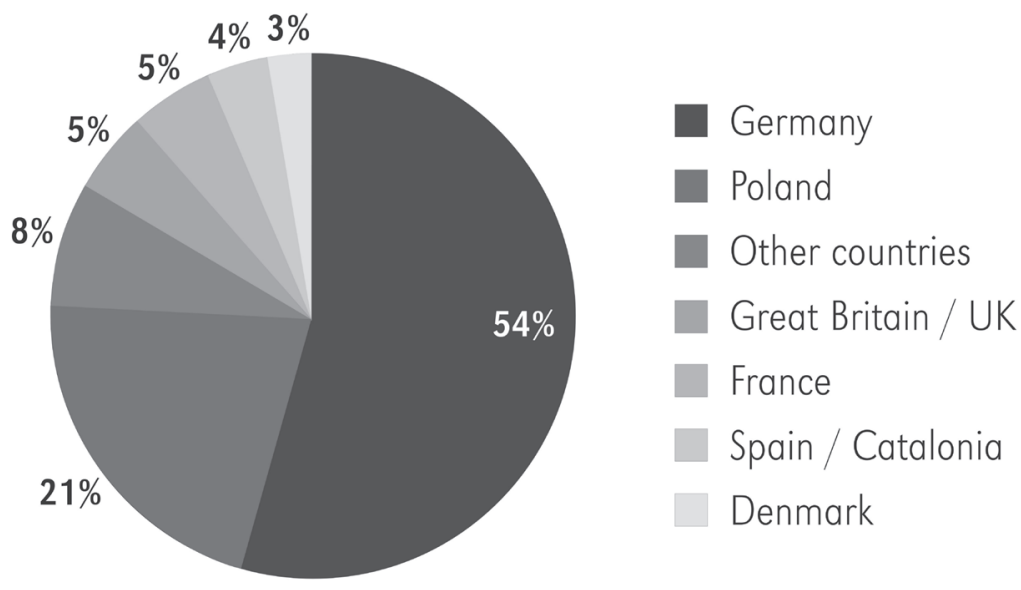

Fig. 1. Geographic distribution of survey participants $(\mathrm{N}=80)$

Figure 2 illustrates for how long participants have been working professionally. The results are overall balanced, showing that both very advanced artists with over 20 years' experience (28\%) as well as newcomers with less than five years' experience $(15 \%)$ took part. 
Q: How many years have you been working as an artist?

$\begin{array}{cccc}\text { Responses; } & \text { Responses; } & \text { Responses; } & \text { Responses; } \\ \text { Less than 5; } & 5-10 ; 29,33 \% & 10-15 ; 28,00 \% & \text { Over 20; } 28,00 \% \\ 14,67 \% & & & \end{array}$

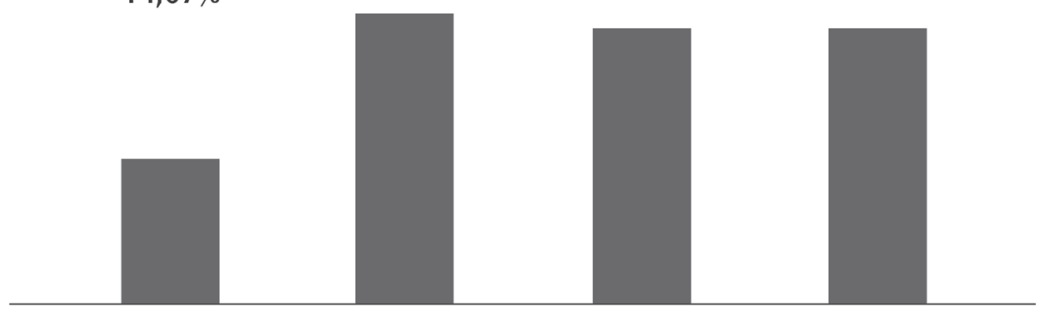

Fig. 2. Indication of professional experience in years $(\mathrm{N}=75)$

In order to determine which artistic fields participating artists work in, the next question referred to their specialization (see fig. 3). Almost half, 43 percent, practice painting, followed by photography, sculpting and installation, each reaching almost ten percent. Further categories such as illustration, digital art and drawing reached 17 percent and were mentioned under 'Other'.

\section{Q: Which artistic field do you work in?}

Responses

Painting;

$42,47 \%$

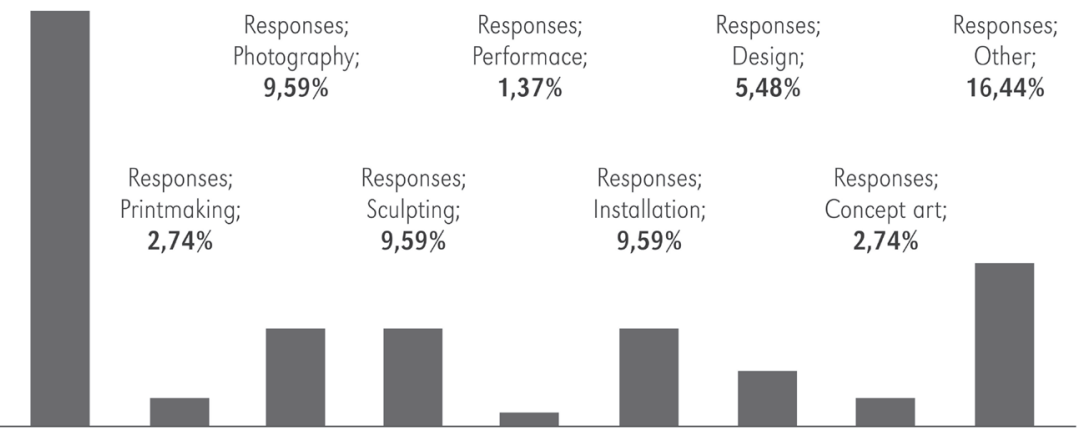

Fig. 3. Indication of artistic field $(\mathrm{N}=73)$ 
After requesting information on artists' biographies and professional experience, the authors proceeded to examine to what degree artists had dealt with texts on art theory, inquiring first whether artists were familiar with relevant texts on art theory, as specified by author (see fig. 4).

\section{Q: Have you read texts by any of the following authors?}

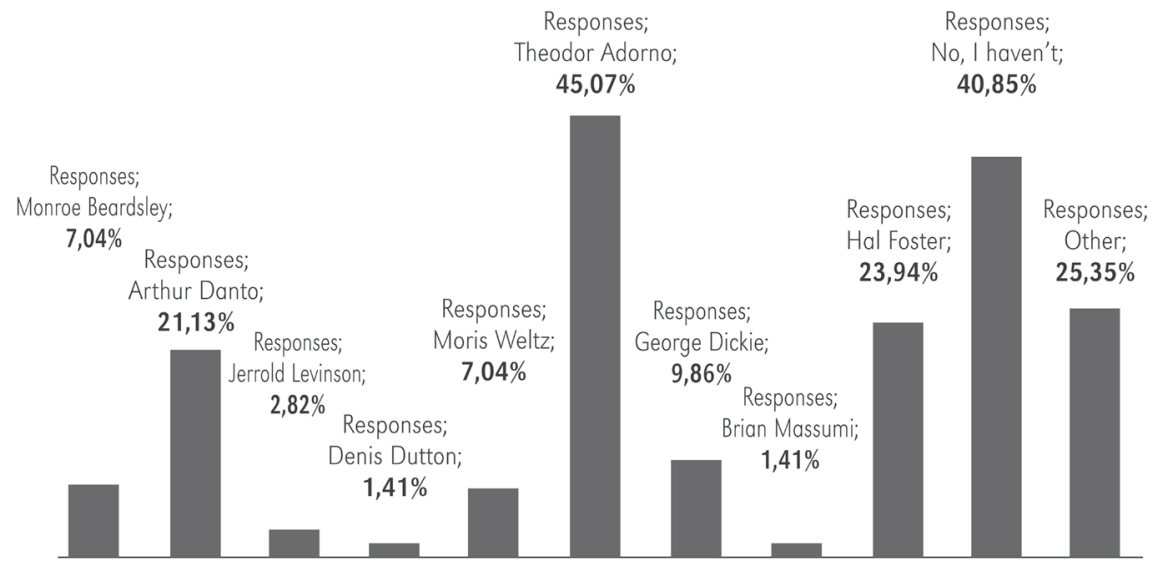

Fig. 4. Indication of renowned authors on art theory (multiple answers possible) $(\mathrm{N}=71)$

Findings show that 45 percent of participating artists had already read texts by Adorno, followed by Foster (24\%), Danto (21\%) and Dickie (10\%). 25 percent of participants listed further authors relevant to them under 'Other' ; these included Sontag, Benjamin, Bachelard and Derrida. Multiple answers were possible. By contrast, 41 percent of the participants - almost half - stated that they hadn't read texts by any of the aforementioned authors.

\section{Q: To what extent have scientific theories on how to define art affected your artistic work so far?}

no affect $(0-20 \%)$
little affect $(21-40 \%)$
neutral $(41-60 \%)$
much affect $(61-80 \%)$
major affect $(81-100 \%)$

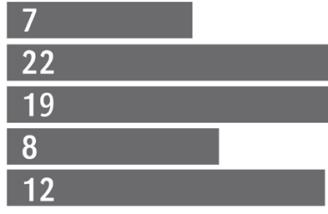

Fig. 5. Indication of the influence of scientific theories on artistic practice $(\mathrm{N}=68)$ 
For the next question, participating artists were able to use a sliding bar to indicate to what extent art theories and definitions of art had influenced them in their artistic practice so far (see fig. 5). While 29 artists stated that art theories had had little or no influence on their artistic work, 20 artists noted that these same theories had played a significant to very significant role in their artistic practice to date.

\section{Q: Have you explored theories on the definition of art during your artistic career?}
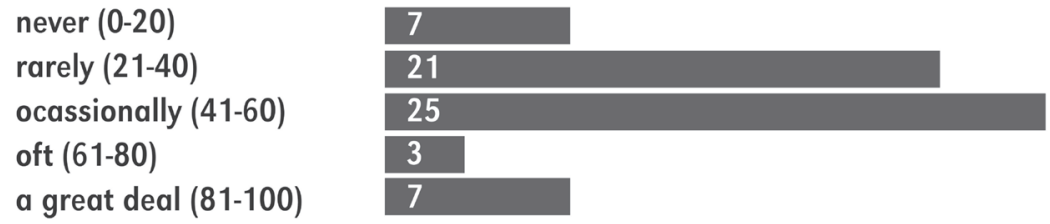

Fig. 6. Indication of engagement with art theories $(\mathrm{N}=63)$

In a next step, the authors further explored the issue by asking artists whether they had engaged with definitions of art during their artistic career (see fig. 6). 28 artists stated that they had never or only rarely dealt with definitions of art; 25 revealed that definitions of art had only been relevant to them occasionally and ten participants reported that they had frequently or very frequently concerned themselves with a definition of art.

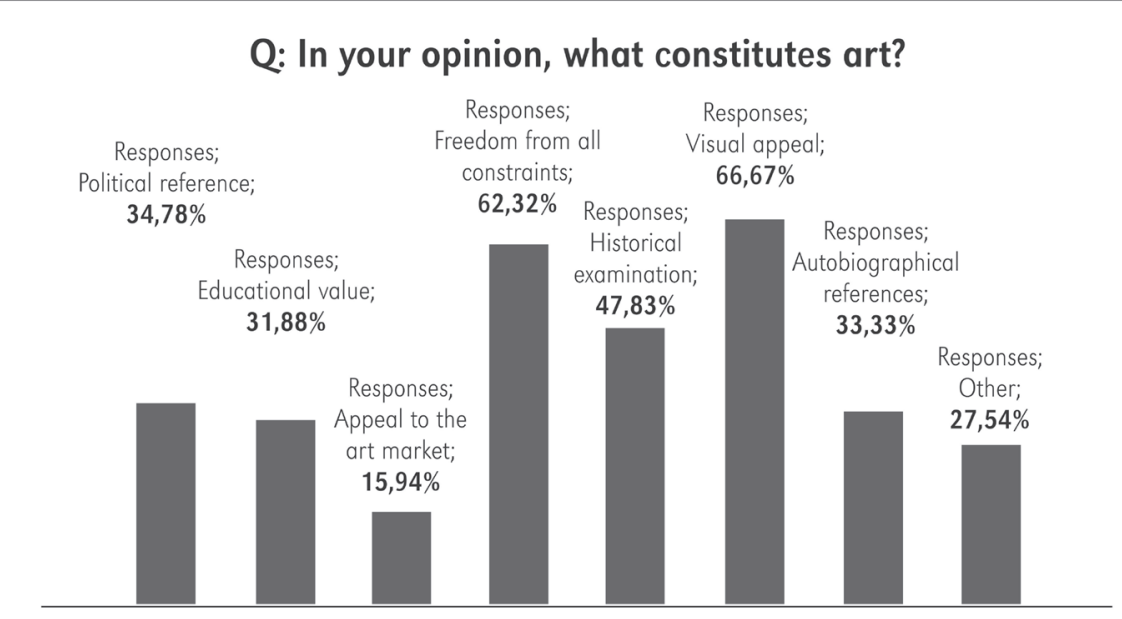

Fig. 7. Relevant criteria for what constitutes art (multiple answers possible) $(\mathrm{N}=69)$ 
Of particular interest to the authors was what participating artists considered constitutes art (see fig. 7). Opinions varied widely; 'visual appeal' prevailed with $67 \%$, followed by 'freedom from all constraints' (62\%) and 'historical examination and confrontation' (47\%). At 16\%, participants deemed the appeal to the art market as relatively insignificant. 28 percent of the artists also mentioned craft and knowledge, concept and native skills under 'Other'.

\section{Q: In your opinion, who ultimately determines what art is?}

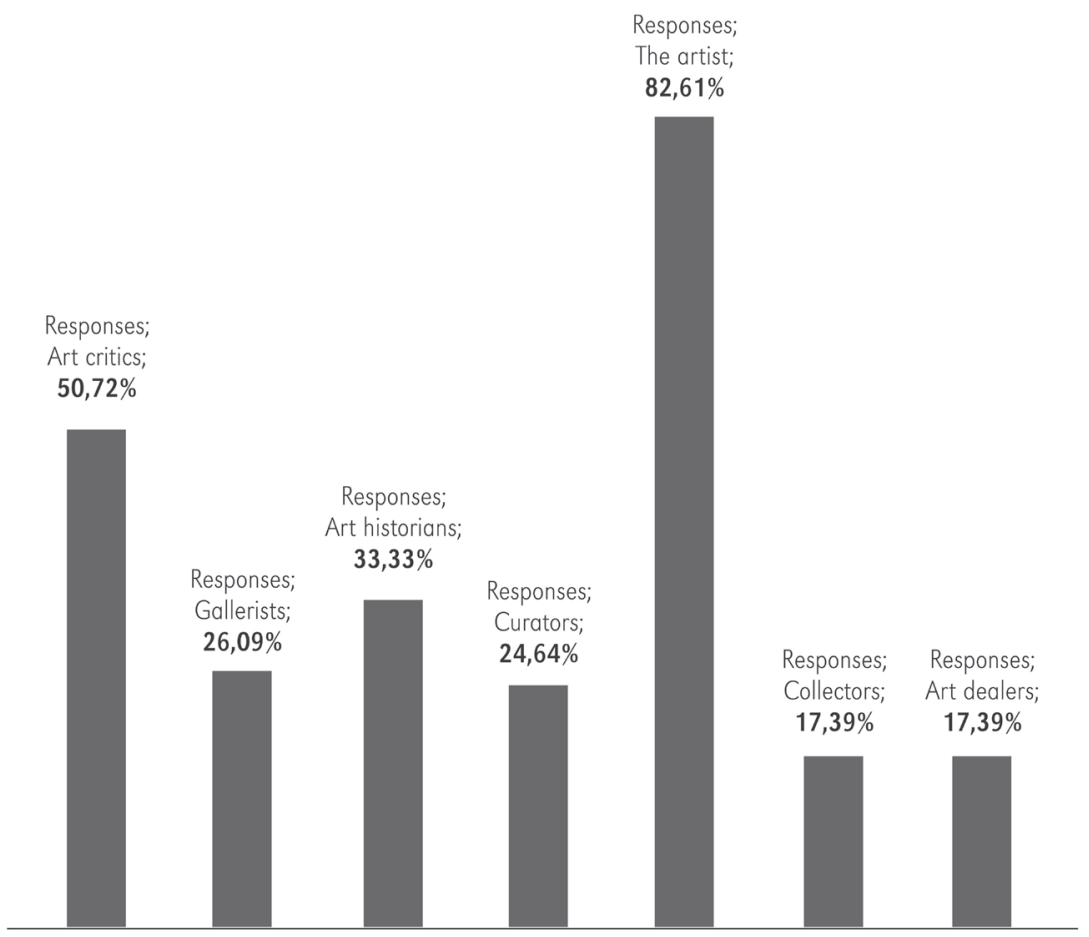

Fig. 8. Key players in the final definition of art (multiple answers possible) $(\mathrm{N}=69)$

To develop an understanding of who ultimately determines what art is from the artists' perspective, participants were confronted with precisely this question (see fig. 8). At 83 percent, participants named artists as the most important agent for determining art. More than half of the participants also cited art critics (51\%), art historians (33\%) and curators (25\%) as major contributors. 
At the end of the survey, participants were asked to what extent they thought that the definition of the term 'art' was at all conceivable from a theoretical perspective. Here, 61 percent of the participants voted in favor of a definition while 39 percent deemed a definition impossible. A Following on from this, it was discussed to what extent artists consider a definition of the term 'art' necessary and relevant. A clear opinion emerged with 20 percent of the artists responding in the affirmative, and 80 percent stating that they didn't deem a definition of the concept of art as necessary.

\section{Discussion}

The aim of this study is to help bridge the research gap that exists when examining possible links between art theory and artistic practice. The results presented above contribute significantly to this issue in that they provide quantitative data on the relationship between artistic practice and art theory.

The 80 artists contributing to the survey form a differentiated picture of the research topic due to their different cities of residence, artistic specialization and professional experience. With the research question in mind, data regarding the influence of art theory on artistic practice (see fig. 5) and the examination of the concept of art (see fig. 6) were of particular interest. Findings show that each play a somewhat smaller role in artistic practice and possibly depend on the artist's educational background (either purely artistic or art historical). While, for instance, 45 percent of the participants were familiar with Adorno's texts on art history, 41 percent stated that they hadn't read any texts by any of the art historians and philosophers proposed in the survey (see fig. 4). A possible explanation may be that artists regard art theories as less important for their work and instead consider other factors more relevant. This hypothesis is also supported by the fact that during their education artists are trained by professors who usually don't hold academic degrees. ${ }^{30}$ These artistprofessors therefore convey an aesthetic approach rather than a scientific one. Additionally, during their artistic training artists might not necessarily be exposed to art theories (at least not through compulsory courses). In fact, artists consider the idea of attempting to enforce a theoretical framework on the concept of art as less favorable. "The idea of research has often made painting go astray, and made the artist lose himself in mental lucubrations," 31 according to Pablo Picasso who critically assessed the relationship between artistic practice

30 E. Lilja, ART, RESEARCH, EMPOWERMENT: On the Artist as Researcher, Elanders Sweden AB, Stockholm 2015, p. 62.

31 H. B. Chipp, Theories of modern art: A source book by artists and critics, University of California Press, Berkeley 1968, p. 264. 
and theory all the way back in 1923 . The results of the survey mirror this same attitude among artists today. While 61 percent of participants believe that the definition of art is possible, 80 percent feel that a definition of art is irrelevant and rather unnecessary. "The only thing that art has to be is not having to be anything", and "It is more about the process of defining rather than a definition by itself" are some of the artists' responses to this question. Clearly, artists appear to reject a uniform definition of the concept of art, envisioning - if at all - a more fluid, ever-changing theoretical construct.

The academic endeavor to develop a theoretical frame of reference for the visual arts seems to succeed only in part; especially in view of the fact that artists themselves don't consider art theory to play a major role in their work, and are even more inclined to critically oppose a definition. Regardless which side puts forward a definition, maybe one participating artist's statement offers a solution both sides could get on board with: "it is important to define boundaries and definitions (of art), even if it just for the sake of overcoming them".

Finally, the survey shows that besides art critics, historians and curators, participants consider artists themselves as the ones who determine what an artwork and thus what art is (83\%). In addition to 'visual appeal', participants state 'freedom from all constraints' as the essence of art. Indeed, it seems quite reasonable that as the creators of artworks, artists should ultimately be more involved in forming theories on art. Sontag suggests that the function of art criticism must be "to show how it is what it is, even that it is what it is, rather than to show what it means". ${ }^{32}$ And Lilja proposes to strengthen artists in their role as researchers in order to distance themselves from interpretive approaches within art history, philosophy and sociology. ${ }^{33}$ Art theory should follow a more flexible, individual approach that doesn't require an absolute categorization of the concept of art. One solution would be to better involve artists in the process. As one artist noted in the survey "the definition of art should be as a work-in-progress, changing all the time" thereby equating the concept of art to a work of art.

\section{Limitations and Implications}

This study aimed to explore the relationship between art theory and art practice and to propose alternative solutions for the definition of art. By evaluating the survey in which 80 visual artists took part, the authors hope to

32 S. Sontag, Against Interpretation: https://jolika.theaterblogs.de/wp-content/uploads/2012/05/ against-interpretation.pdf, p.7 (access: 12 July 2019).

33 E. Lilja, ART, RESEARCH, EMPOWERMENT: On the Artist as Researcher, Elanders Sweden AB, Stockholm 2015, p. 59. 
contribute to the research gap that still exists in this field today. Venturing on relatively new ground, the authors opted for a quantitative research design in order to obtain significant new data. There were, however, some limitations; focusing primarily on the European art market, the study excludes both the US and Chinese markets, whose shares rank highest by country alongside the United Kingdom. Due to the number of participants, sample selection and the nature of quantitative surveys, the findings presented in this article cannot be considered representative. Further research could include an examination of the East Asian as well as North and South American art markets. Comparing these new findings to those of the European artists from this study may offer additional insights.

Despite limitations, the present study has identified key determinants and dynamics that reveal an isolated relationship between art theory and artistic practice. A rather low level of interaction between players on both sides may be one reason as to why a final definition of the term 'art' is precisely so difficult. Improved communication and an increased exchange are possible solutions. For a successful outcome, however, specific measures must be developed and implemented that will ultimately lead to an unbiased exchange - for opposing sides often meet with prejudices.

\section{BIBLIOGRAPHY:}

Abbing Hans (2002) Why Are Artists Poor? The Exceptional Economy of the Arts, Amsterdam: Amsterdam: University Press.

Carroll Noël (2012), Monroe Beardsley, [in:] Aesthetics: The Key Thinkers, Giovannelli Alessandro ed., London, New York: Continuum, pp.160-165.

Carroll Noël ed. (2000) Theories of Art Today, Madison, Wisconsin: The University of Wisconsin Press.

Chipp Herschel Browning (1968) Theories of modern art: A source book by artists and critics, Berkeley: University of California Press.

Costello Diarmuid, Vickery Jonathan (2007) Art: Key Contemporary Thinkers, Oxford, New York: Berg Publishers.

Currie Gregory (2010) Actual Art, Possible Art, and Art's Definition. Journal of Aesthetics and Art Criticism, New Jersey: Wiley, Vol. 68, Nr. 3, pp. 235-241.

Davies Stephen (1991) Definitions of Art, Ithaca, London: Cornell University Press.

Dickie George (1997) Introduction to Aesthetics: An Analytic Approach, New York, Oxford: Oxford University Press. 
Dickie George (2000) Institutional Theory of Art, [in:] Carroll Noël ed., Theories of Art Today, Madison, Wisconsin: The University of Wisconsin Press, pp. 93-108.

Dresdner Albert (1968) Die Entstehung der Kunstkritik im Zusammenhang der Geschichte des europäischen Kunstlebens. Dresden: Verlag der Kunst Dresden.

Hörisch Jochen (27.10.2017) Der Wert der Kunst. Oder: Was leistet Kunst, wer kann und soll sich bildende Kunst leisten? [Lecture Paper]. Berlin: Akademie der Künste, BBK-Symposium „Kunst Wert".

Künstlersozialkasse Deutschland, Voraussetzungen für eine Versicherung bei der KSK: https:// www.kuenstlersozialkasse.de/kuenstler-und-publizisten/voraussetzungen.html (access: 12 July 2019).

Lilja Efva (2015) ART, RESEARCH, EMPOWERMENT: On the Artist as Researcher, Stockholm: Elanders Sweden AB.

Levinson Jerrold (2002) The Irreducible Historicality of the Concept of Art, The British Journal of Aesthetics, Vol. 42, Nr. 4, Oxford: Oxford University Press, pp. 367-379.

McAndrew Clare (2019) The Art Market 2019, Basel: Art Basel and UBS: https://issuu.com/ widewalls6/docs/art-market-report-2019 (access: 17 July 2019).

Sontag Susan (1963) Against Interpretation p.7: https://jolika.theaterblogs.de/wp-content/uploads/2012/05/against-interpretation.pdf, (access: 12 July 2019).

Sontag Susan (1967) Aesthetics of Silence, Aspen no. 5 + 6, Vol. 3. p. 2: http://www.kim-cohen. com/Assets/CourseAssets/Texts/Sontag_The\%20Aesthetics\%20of\%20Silence.pdf (access: 12 July 2019).

Stecker Robert (2012) Plato, [in:] Aesthetics: The Key Thinkers, Giovannelli Alessandro ed., London, New York: Continuum, pp. 8-20.

Taylor Joshua C. (1987) Nineteenth Century Theories of Art, Berkeley/ Los Angeles/ London: University of California Press.

Walker John. A. (2011) Art in the Age of Mass Media. 3rd ed. London: Pluto Press.

Weisstein Ulrich (1992) Literatur und bildende Kunst. Andy Warhol und der Umbau des Kunstbetriebs im 20. Jahrhundert. Frankfurt/Main: Campus Verlag GmbH.

Weitz Morris (1956) The Role of Theory in Aesthetics. The Journal of Aesthetics and Art Criticism. Philadelphia: The American Society for Aesthetics, Vol. 15, Nr. 1, pp. 27-35. 


\section{O NIEZGODNOŚCI NAUKI I SZTUKI - BADANIE ILOŚCIOWE MAJAC̨CE NA CELU OCENĘ ZNACZENIA I STOSOWNOŚCI NAUKOWEJ KONCEPCJI SZTUKI W TWÓRCZOŚCI ARTY- STYCZNEJ} (streszczenie)

Dyskurs naukowy o teoretycznym zdefiniowaniu pojęcia sztuki ma swoje korzenie w greckim antyku. Od tego czasu historia sztuki, filozofia i socjologia sztuki starają się definiować sztu- kę na różne sposoby, niemniej jednak sztuka jako pojęcie ma w swojej naturze ciągłe odkrywanie się na nowo. Dostępna literatura dotycząca tej dziedziny zajmuje się w tym kontekście zazwyczaj badaniem perspektywy naukowo-teoretycznej. Celem artykułu jest podkreślenie artystycznego spojrzenia na poruszaną tematykę i ukazanie, jaką rolę odgrywa naukowe badanie pojęcia sztuki w praktyce artystycznej oraz identyfikacja alternatywnych modeli definicji pojęcia sztuki. Wyniki badania ilościowego przeprowadzonego wśród 80-ciu artystów wizualnych wykazały, że naukowa definicja sztuki ma dla nich mniejsze znaczenie, a wielu z nich uważa nawet, że taka definicja jest zbędna. Zamiast tego, postrzegają oni swoja role na rynku sztuki jako tych, którzy definiują sztukę przed jej historykami lub kuratorami. Można zatem stwierdzić, że istnieje pewna niezgodność w kwestii ostatecznego definiowania pojęcia sztuki między teoretykami sztuki, a artystami wizualnymi.

Na podstawie uzyskanych wyników badania można sformułować wnioski dotyczące dalszego rozwoju w dziedzinie tworzenia koncepcji sztuki. Jedną z propozycji jest silniejsze włączenie artysty w proces naukowy w celu opracowania bardziej elastycznych i dopasowanych modeli teorii sztuki.

Słowa kluczowe: nauka i sztuka, definicja pojęcia sztuki, teoria sztuki, artysta jako naukowiec, sztuka wizualna, badanie ilościowe, ankieta

Sarah Fassio - M.A., research associate and lecturer at the Chair of Cultural Management at the European University Viadrina Frankfurt (Oder) in Germany with several years of professional experience in Berlin's art and gallery scene. She studied Art Histo$r y$ at the Freie Universität Berlin and holds a French-German double master's degree in Arts and Cultural Management. Her academic research focuses on interdependences between the digital transformation of society and the art market. In her current research project, she is exploring the impact of art created by artificial intelligence and how it challenges the classic perception of the art world.

Jessica Hodgkiss - M.A., research associate and lecturer at the Chair of Cultural Management at the European University Viadrina Frankfurt (Oder) in Germany. She completed a foundation course in Art History at the Ludwig Maximilian University of Munich and holds a diploma in Painting and Graphics from the Academy of Fine Arts Munich, which she attended as a Meisterschüler in her final year. She obtained a master's degree in Cultural Management and Tourism at the European University Viadrina Frankfurt (Oder). Her subject of research is the visual artist. She is currently examining the importance of self-marketing for artists. 
Adrianna Rosa - B.A., research assistant at the Chair of Cultural Management at the European University Viadrina Frankfurt (Oder) in Germany, master student of both Cultural Management and Tourism and Languages, Cultures, Communication at the European University Viadrina Frankfurt (Oder). She is particularly interested in intercultural event and project management with a main focus on Poland and Germany. 